
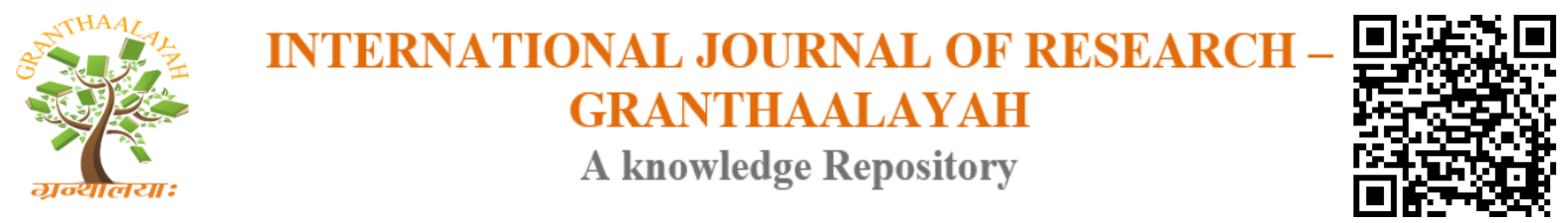

Management

\title{
THE MANAGEMENT OF EXCELLENT SCHOOLS IN INSTILLINGRELIGIOUS BEHAVIOR TO THE STUDENTS OFSTATE HIGH SCHOOLS IN NORTH SUMATERA PROVINCE
}

\author{
Kasman ${ }^{1}$, Mukhtar ${ }^{2}$, Martinis Yamin ${ }^{3}$ \\ ${ }^{1}$ Doctoral Candidate of Islamic Education Management at Sulthan Thaha Syaifuddin State \\ Islamic University, Jambi, Indonesia; Lecturer at STAI Madina Panyabungan Mandailing \\ Natal Regency, North Sumatra, Indonesia. \\ ${ }^{2,3}$ Professor of Suthan Thaha Syaifuddin State Islamic University, Jambi, Indonesia
}

\begin{abstract}
The present research is aimed to determine the management model of excellent schools in instilling religious behavior to the students at state high schools in North Sumatra Province. This research is useful to enrich the scientific paradigm in the field of Management of Islamic Education, especially studies on the management of excellent schools in instilling religious behavior to their students.

The research used qualitative approach. The data collection techniques used observation, interviews and documentations. The data analysis used Milles and Huberman model, while the data analysis technique used data triangulation. The data were collected in excellent state high schools in North Sumatra with these following subjects: (1) SMA Negeri 2 Plus Martabe Sipirok, Tapanuli Selatan; (2) SMA Negeri 1Plus Matauli Pandan, Tapanuli Tengah; (3) SMA Negeri 2 Plus Panyabungan, Mandailing Natal. The results of this research indicate that, first: the success of management of excellent schools is influenced by inputs and processes in determining the output and outcome of the students' religious behavior. Second, the management of excellent schools in North Sumatra involves all components of stakeholders, such as foundations, government, and communities, starting from start planning, implementation and supervision and financing. Third, the religious behavior of students in North Sumatra constitutes "aqidah/ Faithful Behavior", namely the students' faith in their religion; "Worship behavior", namely the act of religious rituals in schools; "Almsgiving behavior", as seen in discipline, cleanliness maintenance, mutual assistance in pluralism; "Ihsan/ Good Deeds Behavior", namely the students' sincerity in worships and almsgiving; "Knowledge Behavior", namely the students' knowledge of the teachings of their religion. Fourth, the management of excellent schools in North Sumatra in instilling the students' religious behavior, that is integrated in the humanistic learning approach system, full-day school and boarding school programs.
\end{abstract}

Keywords: Excellent Schools; Religious Behavior.

Cite This Article: Kasman, Mukhtar, and Martinis Yamin. (2018). "THE MANAGEMENT OF EXCELLENT SCHOOLS IN INSTILLINGRELIGIOUS BEHAVIOR TO THE STUDENTS 


\section{Introduction}

Basically, there are two very useful models of approaches in establishing an excellent school, i.e. the model approach to achieving objectives and model approach to the process. This approach model of goal achievement, which is based on the traditional view of the organization, is said to be effective when it reaches its intended goals (Sergiovani: 1987: 41). At school, the level of achievement is normally seen by the achievement of school graduates. This approach model of goal achievement, that is the students' achievement is an important role used in determining whether or not the school is included as the excellent ones. As for the process approach model, this model views the organization as an open system, consisting of input transformation and output. This organizational effectiveness system model is seen not from the level of goal achievement; rather from the internal consistency, efficient use of all available resources, and the success in their working mechanisms. There are two underlying assumptions: (1) the organization is an open system that must be able to utilize and reflect the surrounding environment; (2) the organization is a dynamic system and is so large, so that the requirement is increasingly complex, and it is impossible to be defined based only a small number of meaningful organizational goals. Schools, therefore, can be called an excellent school if it has high effectiveness characteristics, such as positive school climate; school planning process that involves all school residents; high expectations of academic achievement; effective monitoring of students' progress; teachers effectiveness; instructional leadership oriented to academic achievement; active parent involvement in school activities; opportunities, responsibilities, and high students' participation in the school; rewards and incentives at school based on success, manner and good discipline in school; and implementation of clear curriculum. The model of state high school is also able to attract public interest. It is not exaggerating to say that this educational institution deserves to be called a favorite school, an effective school or a prominent school which holds much hope for the people, especially when it comes to its competitive quality and management that have advantages, compared to other equivalent schools. Religious behavior means any act of deed or speech that a person does, while his acts, actions and speeches are related to religion, all of which are because of his belief in God, alongside the teachings, worship and duties associated with belief. With regard to the educational paradigm contained in article 1, paragraph 1 as mentioned above, Article 1, Paragraph 2 of Law no. 20 of 2003 stipulates that: "National Education is an education based on Pancasila and the 1945 Constitution of the Republic of Indonesia, rooted in the values of religion, national culture of Indonesia and is responsive to the changing demands of the times." In an effort to embody the values of religion in school, it is necessary to provide spiritual enlightenment to build noble character or manner through habituation activities, such as: habituation to say greetings, to do dzuhur/ sunset prayers in congregation and dhuha prayers, almsgiving, Qur'an recitation, and the big day of Islam commemoration.

\section{Research Methods}

The approach used in this research was qualitative descriptive. The characteristics of qualitative research as explained by Robert are: the appeal of qualitative research is that the research allows you to conduct an in-depth study on vast unity of topics, including your favorites, in terms of 
simplicity and daily relationships. In addition, larger latitudinal researchers prefer interesting topics, as other research methods are likely to be limited by: 1) inability to establish the necessary research conditions (as in experiments); 2) unavailability of adequate data or lack of sufficient coverage of variables (as in economic studies); 3) difficulty in describing adequate sample of respondents and getting high response (as in surveys); other limitations are specialized to study of past events, but not the sustainable ones (as in history). (Robert K. Yin: 2011: 6). The present research takes on the social situation at SMA Negeri 1 Plus Matauli Pandan, Tapanuli Tengah; SMA Negeri 2 Plus Martabe Sipirok Tapanuli Selatan; SMA Negeri 2 Plus Panyabungan Mandailing Natal. The social situation occurred was in the form of activities of school principals and school residents in the school management to instill religious behavior to the students. The reason why the researcher chose these three schools above as the research site are:

1) These three state high schools are the representative of each region located in the southern, eastern, and western region of North Sumatra Province.

2) These three state high schools are compatible for this research, in terms of examination to excellent schools' management in instilling religious behavior of the students at state high schools in North Sumatra Province.

3) The problems under study are found in these three schools, namely the instillation of the students' religious behavior.

4) The researchers' affordability, in terms of the residence of the researchers, both in terms of energy and time efficiency, making it easier for researchers to access research data.

5) Researchers have yet found a previous research that examined the things mentioned above in three state high schools in North Sumatra Province.

The data collection technique used observations, interviews and documentations. Data analysis used Milles and Huberman models, which was started by reduction, display and conclusion (Milles and Huberman: 2014: 6). Data analysis technique used the data triangulation technique.

\section{Research Findings and Discussions}

\subsection{The Success of Management of Excellent Schools in Instilling Religious Behavior to the Students in North Sumatra}

SMA Negeri Plus 2 Martabe Sipirok Tapanuli Selatan, SMA Negeri 1 Plus Matauli Pandan Tapanuli Tengah, and SMA Negeri 2 Plus Panyabungan Mandailing Natal are state schools which were initially established on the initiative of people who desired an excellent and quality school. This community's initiative is based on the fact that Tapanuli Selatan, Tapanuli Tengah and Mandailing Natal areas are religious areas, thus requiring school graduates with intellectualism and academic quality and religiosity, according to the culture and customs in that area.

The fundamental difference among SMA Negeri Plus 2 Martabe Sipirok Tapanuli Selatan, SMA Negeri 1 Plus Matauli Pandan Tapanuli Tengah, and SMA Negeri 2 Plus Panyabungan Mandailing Natal, is the management system. The management SMA Negeri Plus 2 Martabe Sipirok Tapanuli Selatan and SMA Negeri 1 Plus Matauli Pandan Tapanuli Tengah is carried out by a cooperation body belonged the government and foundation; while the management of SMA Negeri 2 Plus Panyabungan Mandailing Natal is only done by local government. 
An excellent school is a school with an excellent program that is brought forth from a desire to have a school with national and international achievement, mastery of science, skills and technology, and supported by akhlakul karimah. To achieve these advantages, the input, processes and supporting facilities should be directed to support the achievement of these goals. The successful management of SMA Negeri Plus 2 Martabe Sipirok South Tapanuli, SMA Negeri 1 Plus Matauli Pandan Tapanuli Tengah, and SMA Negeri 2 Plus Panyabungan Mandailing Natal, in instilling religious behavior of the students has been supported with inputs and processes in favor of students' output equipped with such desired religious behavior.

The empirical data obtained by researchers on the field, related to the success of the excellent schools SMA Negeri Plus 2 Martabe Sipirok South Tapanuli, SMA Negeri 1 Plus Matauli Pandan Tapanuli Tengah and SMA Negeri 2 Plus Panyabungan Mandailing Natal, in the instillation of students' religious behavior in general, can be shown in the following figure:

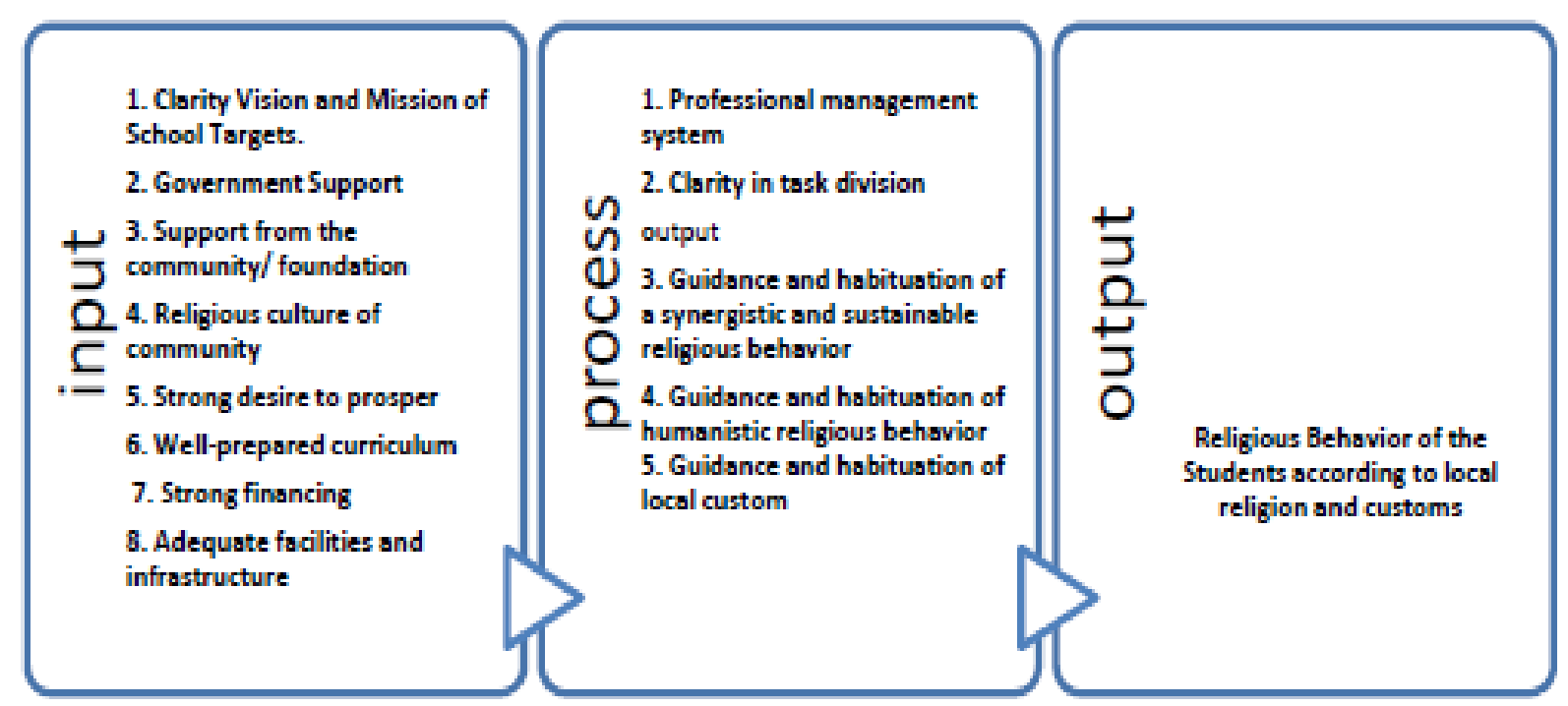

Figure 1: Input, Process and Output of the Management in Instilling Religious Behavior to the Students of Excellent High Schools in North Sumatra

Ontologically, excellent schools included in the perspective of the Ministry of National Education are those developed to achieve excellence in the output of education. To achieve these advantages, then the inputs, educational processes, teachers, education personnel, management, education services, and supporting facilities should be directed to support the achievement of these targets. Therefore, an excellent school can be defined as a school developed and managed as good as possible, by directing all its components to achieve better and more proficient graduate outcome than that of other school.

The background of the emergence of excellent schools is the enactment of Law No.20 of 2003 on the National Education System which puts schools as a part of the national education subsystem. Schools are also required to innovate and renew themselves, both in terms of institutional and the output quality. The expected output quality has been conceptualized in the 1945 Constitution Article 31 Paragraph 3, which states that the government seeks and organizes a national education system to enhance faith and devotion and noble morality. 
It is reaffirmed in UUSPN No 20 of 2003 Article 3, stating that: "Indonesian national education serves to develop the abilities and form the character and civilization of dignified nation, in order to educate the life of the nation, to develop the potential of learners into human beings with faith and piety to God Almighty, nobility, health, knowledge, capability, creativity, independency and into democratic and responsible citizens." In fact, excellent schools earn the support of the community, as seen in their desire to send their children to excellent schools, regardless of the tuition required.

In the context of educational institutions, the term excellent can be linked to schools which give rise to new desire and passion within the educational organization, for instance innovative schools which seek for better quality and are superior to other schools. This effort requires the input schools not only to have aspirations and desires alone, but the needs for excellent achievement in all of their aspects. (Agus and Zaenul: 2010: 26). The success of excellent school management is based on the vision of the school: the realization of society and Indonesia with religious attitude, scientific-diniah abilities, skills and professionalism. Under this vision, the management of excellent schools is directed towards the realization of individual students with religious, scientific in- depth, skilled and professional behavior according to the order of life.

The success of excellent school management should also get support from the government and the community. Without the support of all parties, especially the stakeholders, the management of excellent schools in instilling religious attitude to the students is nonsense. The support from the stakeholders and school shareholders will give measurable financing assistance. Financing is a major factor in school success. In this case, SMA Negeri 2 Plus Martabe Sipirok South Tapanuli and SMA Negeri 1 Plus Matauli Pandan Tapanuli Tengah, make cooperation in financing and management conducted by the foundation and the government. Meanwhile, SMA Negeri 2 Plus Panyabungan Mandailing Natal is a pre-eminent school established by the Mandailing Natal Regency Government, based on the awareness that Mandailing Natal community needs schools that can produce graduates with religious behavior according to the culture and customs of the religious Mandailing Natal's society. The management of SMA Negeri 2 Plus Panyabungan is certainly supported by the surrounding society.

The success of excellent school management of SMA Negeri 2 Plus Martabe Sipirok South Tapanuli, SMA Negeri 1 Plus Matauli Pandan Tapanuli Tengah, and SMA Negeri 2 Plus Panyabungan Mandailing Natal, is based on the strong desire of each member of the school to prosper and create improving quality, by means of producing students with academic quality and religious behavior. This strong desire will lead to the reform and development of educational resources and professional educational personnel who provide education services. The presence of professional educators and personnel will facilitate the school management in the instillation of religious attitude of the students.

The success of excellent school management SMA Negeri 2 Plus Martabe Sipirok South Tapanuli, SMA Negeri 1 Plus Matauli Pandan Tapanuli Tengah, and SMA Negeri 2 Plus Panyabungan Mandailing Natal, is supported by the presence of adequate facilities and infrastructure. The presence of schools supported by beautiful comfortable, peaceful dormitories and mosques will strongly boost the success in instilling religious behavior to the students. Direct learning activities 
in schools can be applied in the dormitories as a habitation for religious behavior of students in daily life.

\subsection{Formulation of Excellent School Management in North Sumatra}

\subsubsection{SMA Negeri 2 Martabe Sipiro Tapanuli Selatan}

The management of the excellent school in SMA Negeri 2 Martabe Sipirok Tapanuli Selatan was implemented based on the Regulation of the Minister of National Education of the Republic of Indonesia number 19 of 2007 on the standard of school management. SMA Negeri 2 Plus Martabe has been able to meet and exceed the management standards established through the Minister of National Education Regulation No. 19 of 2007, and the National Education Standards Agency (BSNP). The excellent management of SMA Negeri 2 Plus Martabe Sipirok is that this school has implemented a full-day school and boarding school program. Furthermore, the other school management's excellency is: this school has been managed not only by Local Government, but also by Yayasan Pendidikan Marsipature Hutana Be (YPMHB)/ Educational Foundation of Marsipature Hutana Be. In terms of planning, the implementation of supervision and financing, this foundation always contributes to SMA Negeri 2 Plus Martabe. Therefore, the existence of SMA Negeri 2 Plus Martabe is different from other schools in South Tapanuli.

\subsubsection{SMA Negeri 1 Matauli Pandan Tapanuli Tengah}

Excellent School Management of SMA Negeri 1 Plus Matauli Pandan has fulfilled and exceeded the National Standard of Education, both in terms of Standards Competency Graduates, Content of Education Process Standard, Education Personnel Standard, Facilities and Infrastructure Standards, Education Management Standards, Education Appraisal Standards. The excellent management at SMA Negeri 1 Plus Matuli Pandan is found in the application of ISO 9001: 2008 Quality Management Systems which makes the school as the center of excellence.

The excellency of SMA Negeri 1 Plus Matauli Pandan is found in the management of science and technology-based education. It is quite basic because of the complete instructional facilities and infrastructure. The complete learning facilities and infrastructure are inseparable from the commitment and support from Matauli Foundation in the improvement of this school. The foundation always builds external cooperation in school financing to supplement school facilities and infrastructure.

The excellent management of SMA Negeri 1 Plus Matauli Pandan can also be seen from the management of human resources, be it in terms of educators, educational staffs, and the graduates who get accepted in many universities, schools of education, and other higher education institutions. SMA Negeri 1 Plus Matauli always puts forward the process and results in its management. 


\subsubsection{SMA Negeri 2 Plus Panyabungan Mandailing Natal}

The excellent management SMAN 2 Plus Panyabungan can be seen from the election of this school into a reference school in Mandailing Natal Regency. With this election, this school can develop the quality of education. This program is contained the program of Directorate of Higher Education, Ministry of Education and Culture. The excellence of SMA Negeri 2 Plus Panyabungan is found in the full-day school program and boarding school program. This program makes this school different from other schools in Mandailing Natal Regency. Under this program, SMA Negeri 2 Plus Panyabungan can implement special skill programs into the schools and in dormitories. Under this program, extracurricular activities in SMA Negeri 2 Plus Panyabungan can be more complex.

\subsection{Instillation of Religious Behavior to the Students in North Sumatra}

The instillation of religious behavior to the students at SMA Negeri 2 Plus Martabe Sipirok, SMA Negeri 1 Plus Matauli Pandan, and SMA Negeri 2 Plus Panyabungan can be done by: 1) instilling a religious culture in the campus' environment and life. It is in accordance with the described above (Asmaun Sahlan, 2010: 85) which creates a religious atmosphere among fellow teachers, between teachers and learners, between learners and other learners. It can be done by saying greetings and nice words during meeting or separation; initiating or ending the act with prayer; asking opinions or questions in a kind way; being courteous; behaving politely; and not degrading other learners.

These are the instillation of religious behavior for the students, and it will become the embryo which ultimately brings religious culture into school. Religious culture is used as a vehicle for the inculcation of religious values, and the instillation of religious behavior for the students. The inculcation of religious values is the beginning in the instillation of religious behavior to the students.

2) Performing habits of good deeds in the daily interaction. It is in line with the findings in this research showing that these three schools have been accustomed to: (a) greet; (b) say hello and smile; (c) pray in congregation. I is in accordance with Talizidhu's opinion (2010: 24) which explains that: The approach of habituation, exemplary and persuasive approach, or invitation to the school citizens done in a subtle way, for instance by providing good reasons and prospects, can eventually convince them. The attitude of activities should be proactive, namely by making action on their own initiative; determining the kind of direction on their own initiative; and reading the emergence of actions to contribute to the color and direction of the religious value development in schools that will ultimately instill the religious behavior to the students.

The explanation related to the religious behavior of students at excellent state high schools in North Sumatra can be shown below:

Behavior of students at excellent high schools in North Sumatra is an activity that emerges from within the students, as resulted from environmental situation that formed them. In this case, the situation at excellent high schools in North Sumatera has been designed to instill students' religious behavior. State high schools in North Sumatera have sought the instillation of students' 
religious behavior by providing a pleasant educational service, complete with facilities and infrastructure, beautiful environment, and peaceful atmosphere. This effort is an attempt to change students' attitude, in responses to school culture and religion, discipline and mutual respect. Therefore, it is expected that there will be changes of students' attitude, followed by the students' religious behavior towards a better direction. This can be described in the following figure:

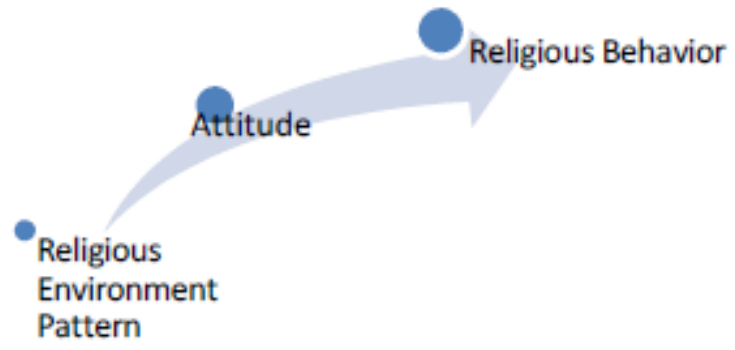

Figure 2: Relationship of Students' ReligiousBehavior Formation

Behavioral change is determined by changes in the attitude towards something. That is, if someone wants to change the direction or behavior of a person, they must change their attitude first.

The tendency to behave is a logical consequence of an individual's beliefs and feelings toward an object. If someone is sure that the object is good, then she/ he must be ready to accept the object as well. It is consistent with the opinion of Feierman, Shilpa Kumari and Glock and Stark, in which they agree that religious behavior can come in the form of a social situation created in the environment. This theory is also in line with the theory of Stimulus and Response (S-R) initiated by Ivan P. Pavlov $(2010 ; 136)$. The core concept of the S-R theory is that if the stimulus gives a positive or rewarding effect, the response to the stimulus will be repeated on another occasion, where the same stimulus emerges; otherwise, if the responses give a negative effect (punishment and so on), then the relationship between the stimulus and response will be avoided on another occasion. A person's religious behavior is formed when there is a stimulus provided by the school, through adequate activities and or equipment and infrastructure that will result in a religious attitude and ultimately show the students' positive and religious behavior.

The religious behavior of students at excellent high school in North Sumatra is manifested by the symbols of the diversity in ritual activities, embodying social life as reflected by the values and norms of local customs. The majority of the students at SMA Negeri 2 Plus Martabe Sipirok and SMA Negeri 2 Plus Panyabungan Madailing Natal are Moslems, so the rituals and symbols created in the school and dormitory are made according to symbols and images in Islam. Besides, Tapanuli Selatan and Mandailing Natal are Muslim-majority areas. It makes the cultures in this school to become those that reflect Islamic culture. This is evident from the explicitly-stated vision and mission of the school.

It is in contrast to SMA Negeri 1 Plus Matauli Pandan Tapanuli Tengah. Although the majority of Central Tapanuli residents are non-Muslim, the values and norms created in this school are based on religious values in general, such as mutual respect, honesty, discipline and mutual assistance. These values do not conflict with the values and norms in Islam. These values and norms are 
included in the almsgiving dimension in the students' religious behavior. The almsgiving dimension of students' religious behavior is the measurement of the extent to which a person's behavior is motivated by his/ her religious teachings in life.

Religion has a function because religion is not an illusion; instead, it is an identifiable social fact and has social importance. Religion deals not only with high-value objects or the very end resort for individuals or society, but also with the maintenance and development of life in all things. A person's religious behavior is manifested in all sides of their life. Religious activity is not only happening when a person performs a ritual (worship), but also when a person performs another activity that is driven by supernatural powers. It is not only related to noticeable and visible activity to the eye, but also invisible and occurring activity in one's heart. The social behavior dimensions of excellent state high schools in North Sumatra can be described as follows:

\subsubsection{Aqidah/ Faith}

The dimension of faith in the students' religious behavior is the belief or faith towards calming entity within everybody's heart. High school students in North Sumatra have been able to apply the faith, making their religious behavior appear in their daily activities. In doing daily activities in the dormitories or at schools, high school students in North Sumatra are arguably showing their religious behavior. It is impossible for a person to practice religious rituals without being based on faith to the religion itself. The dimension of faith in religious behavior is a key dimension in instilling other dimensions in religious behavior. Regarding the principles or contents of faith, in Qur'an Surah Al-Baqarah Verse 285, Allah says:

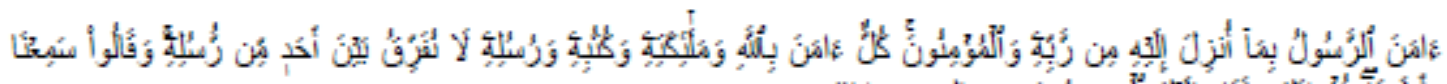

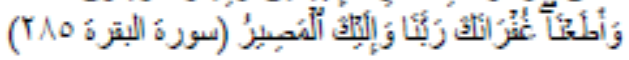

Meaning: The Messenger believes, and so do the believers, in the guidance sent down upon him from his Lord: each of them believes in Allah, and in His angels, and in His Books, and in His Messengers. They say: "We make no distinction between any of His Messengers. We hear and obey. Our Lord! Grant us Your forgiveness; to You we are destined to return."Q.S. Al-Baqarah: 285).

The students of excellent high school in North Sumatra have shown the faith dimension of religious behavior which is proven in their faith towards the truth of Islam, especially on the main points of faith in Islam, concerning the belief in God, Angels, books, Prophets and Apostles, Doomsday, Qadla and Qadar. This embodiment of faith and belief is then applied to behaviors reflecting each of their religions.

\subsubsection{Worships}

The worship dimension in the religious behavior of the students at SMA Negeri 2 Plus Martabe Sipirok South Tapanuli, SMA Negeri 1 Plus Matauli Tapanuli Tengah and SMA Negeri 2 Plus Panyabungan Mandailing Natal, is depicted from Islamic religious rituals that regulate students' relationship with God, such as obligatory prayers, fasting and Qur'an recital. 
SMA Negeri Plus 2 Martabe Sipirok Tapanuli Selatan and SMA Negeri 2 Plus Panyabungan are schools that come with boarding school programs. In this case, the instillation of students' religious rituals in the worship dimensions includes prayer, fasting and zakat. It can also be directly controlled by school administrators and foundations that synergize their respective duties. The worship rituals performed by students in these two schools show the presence of religious behavior; and it serves an indicator of students' religious behavior in terms of worship dimension. Meanwhile, religious behavior of the students at SMA Negeri 1 Plus Matauli Pandang Tapanuli Tengah is more focused on the almsgiving dimension. It is quite reasonable because of the heterogeneous state of the students in this school.

\subsubsection{Almsgiving}

The almsgiving dimension of the students at state high school in North Sumatera is generally seen from the social activities of students, such giving charity, helping friends, and respecting older people. The almsgiving dimension in the students' religious behavior is a measurement of someone's behavior which is motivated by their religious teachings in life. This almsgiving dimension is a balance between the vertical element (hablum min Allah) and the horizontal element (hablum min an-Nas) within the students.

The students at excellent state high schools in North Sumatra do not only perform ritualistic religious activities. Rather, they are taught to develop social religious behavior as an indicator of almsgiving dimension in the behavior of diversity. Ritual worships must also be balanced with social worship. Social worship in this research is included in the almsgiving dimension. Ritualistic activities without almsgiving will result in an imbalance of a Muslim in his/ her religious behavior. It is in accordance with the word of Allah in Surah al-Qashash Verse 77:

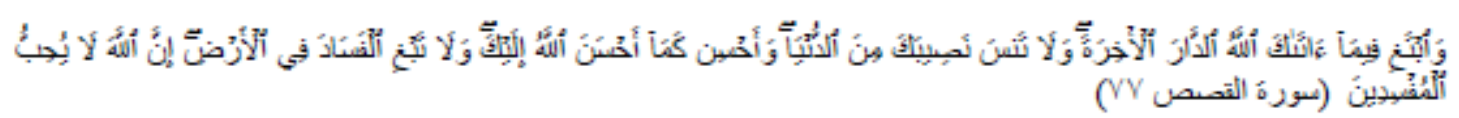

Meaning: "But seek, with that which Allah has bestowed on you, the home of the Hereafter, and forget not your portion of lawful enjoyment in this world; and be generous as Allah has been generous to you, and seek not mischief in the land. Verily, Allah likes not the mischief-makers." (QS. Al-Qashash:77).

In that verse, Allah commands His servants to pursue the afterlife and good social living with others by doing social activities. In that verse, Allah clearly commands good deeds to fellow human beings and forbids doing mischief on earth. The road to the afterlife does not done only by practicing ritual worship, but also good deeds to fellow human beings. This balance is better known as hablu min Allah and hablu min an-nas.

Many people diligently perform worships, yet their involvement in the social activities for fellow humans is less visible. Many people also diligently get involved in social activities, yet their worships activity is insufficient. 
Such behavior does not exhibit perfect religious behavior. Only a balance between religious ritual activities and social activities for other people, such as helping friends, giving charity, doing social service activities, engaging in mutual assistance and other activities in schools will form religious behavior in the students.

\subsubsection{Ihsan/Good Deeds}

The religious behavior of the students at excellent state high schools in North Sumatra in the Good Deeds dimension is balancing the dimension of worship and the dimension of almsgiving. Good deeds dimension is related to the feelings, perceptions and sensations experienced by the students, or the religious experience as a communication with God, with the ultimate realty or with the transcendental authority.

Good Deeds dimension in the religious behavior of students at excellent state high schools in North Sumatra is the sensation and feelings in implementing the dimensions of Faith, Worships and Almsgiving. The faith dimension of the students' religious behavior is doing good deeds in every aspect maximally, until it reaches the highest level of perfection: seeing Allah SWT with the inner eyes. It can also be interpreted as having an attached deep conviction of the All-Seeing God or Pansophical God.

Views on this Good Deeds dimension are basically focused on three meanings. The application of the meaning of Good Deeds may be integral and is inseparable from one another. The meaning is, first, Good Deeds is to do a job (charity) as good as possible, as beautiful as possible, and as perfect as possible; second, Good Deeds dimension is doing good things or nice things to anyone; third, Good Deeds is giving favors or benefits to other parties. The religious behavior of the students is found in religious activities in excellent state high schools at North Sumatra, which is integrated with one another. Activities of worships and social charities of the students there are not only done in ceremonial aspect, but are also done as good as possible to seep into the soul of each student. Good Deeds is described by Allah in An-Nisa' Verse 125:

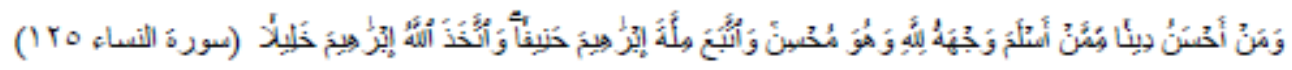

Meaning: And who can be better in religion than one who submits his face (himself) to Allah; and he is a Muhsin (a doer of good). And follows the religion of Ibrahim the Hanif (Monotheist). And Allah did take Ibrahim as a Khalil (an intimate friend)!) (126. And to Allah belongs all that is in the heavens and all that is in the earth. And Allah is Ever Encompassing all things.) (Q.S. AnNisa': 125).

Therefore, in Good Deeds, it can be emphasized that the intention of God is also absolute matter. A person who performs good deeds according to Islamic teachings, but does not intend such thing for Allah Almighty, cannot be regarded as an action of Ihsan/ Good Deeds. For a Muslim, the degree of Good Deeds is the most perfect one. The degree of Good Deeds is achieved through the worship containing raghbah wa thalab (wanting and searching), so that he may see God. A person who has attained this degree of Good Deeds can feel muraqabah, hence the improvement and refinement of his/ her deeds. 
The main focus of Good Deeds is not located at his/ her actions; rather, the main focus of it is found in the heart of a Muhsin. A Muhsin totally and sincerely surrender to Allah, is worthy of being considered as the best religious devotee. He is the one who embodies his worship until he reaches the perfection of monotheism, excels in his belief, and practices almsgiving as best and as perfect as possible.

\subsubsection{Knowledge}

The dimension of religious knowledge serves as the intellectual dimension of religious behavior of the students at excellent state high schools at North Sumatra. It refers to the students' knowledge on the basis of Islamic beliefs, rituals, scriptures, and religious traditions. The knowledge dimension of the students there can be seen from their ability to understand the religious concepts that they believe in. Students with sufficient religious knowledge will be kept away from blind acts of Taqlid (bandwagon effect), and Khurafat (superstitions) that are misleading in lives.

Students of SMA Negeri 2 Plus Martabe Sipirok once won a regency-level Arabic speech in succession, from 2015 to 2017. Similarly, SMA Negeri 2 Plus Panyabungan once won an Islamic education quiz competition at provincial level in 2016 and 2017. The achievement of these two high schools is an example of the students' religious knowledge dimension. In addition, SMA Negeri 2 Plus Martabe Sipirok at every end of the even semester has the agenda of spiritual tourism activities. In this agenda, they go and visit historic place with Islamic nuance, such as the tomb of Sheikh Barus in Tapanuli Tengah, Tuanku Tambusai in Pekan Baru, Tuanku Rao in Pasaman Timur, West Sumatra. These activities can also build the students' religious knowledge, as included in the religious behavior. The activities of religious lectures is done in rotation; while the mentoring system in SMA Negeri 2 Plus Panyabungan conducted after every dawn prayer is also included in activities that can build the students' religious knowledge.

Knowledge is essentially a gift from Allah. In fact, the achievement of success in the world and the hereafter has to be done through knowledge, both religious knowledge and general knowledge. Allah SWT will raise the dignity of knowledgeable people, as contained in Al- Mujadilah Verse 11:

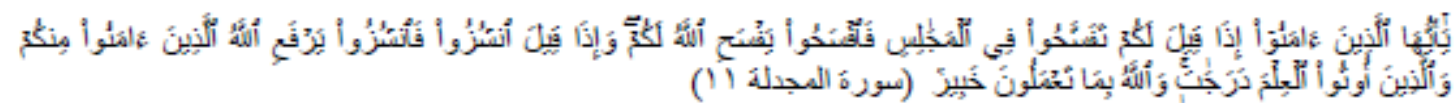

Meaning you who believe! When you are told to make room in the assemblies, make room. Allah will give you room. And when you are told to rise up, then rise up. Allah will exalt in degrees those of you who believe, and those who have been granted knowledge. And Allah is WellAcquainted with what you do.) (Q.S,Al- Mujadalah: 11).

The knowledge of an 'alim (knowledgeable people) makes his degree of devotion different from that of a believer (other than 'alim). Therefore, an 'Alim is exemplified in every deed; whereas those other than an 'Alim should not be emulated, because an 'Alim knows how to shun himself from forbidden things and syubuhat things (things not clearly defined as haram or halal); knows how to do self-evaluation (muhasabatunnafs), knows how to be solemn/ khusu' and worships in a manner unknown to other people unless an 'Alim himself; knows the way for repent/ Taubat and its time; and always maintains and practices unknown rights other than an 'Alim. However, with great power and high position of an 'Alim in terms of reward and degree for his obedience, comes 
great punishment for him when he sins. The students of excellent state high schools at North Sumatra have shown their religious behavior, be it from the dimension of aqidah/ faith, ibadah/ worships, amal/ almsgiving, ihsan/good deeds, and knowledge. These five dimensions are strongly influenced by the school environment that develops a religious culture. The culture and school environment created by religion have an effect on to the students' religious behavior which can further develop under the dominance of attitude, behavior and the habits of school environment. The most important thing in the instillation of religious behavior to the students in SMA Negeri 2 Plus Martabe Sipirok Tapanuli Selatan, SMA Negeri 1 Plus Matauli Pandan Tapanuli Tengah and SMA Negeri 2 Plus Panyabungan Mandailing Natal, is the formation of the students' faith. The description of the students' religious behavior at SMA Negeri 2 Plus Martabe Sipirok Tapauli Selatan, SMA Negeri 1 Plus Matauli Pandan Tapanuli Tengah and SMA Negeri 2 Plus Panyabungan Mandailing Natal can be seen in the following figure:

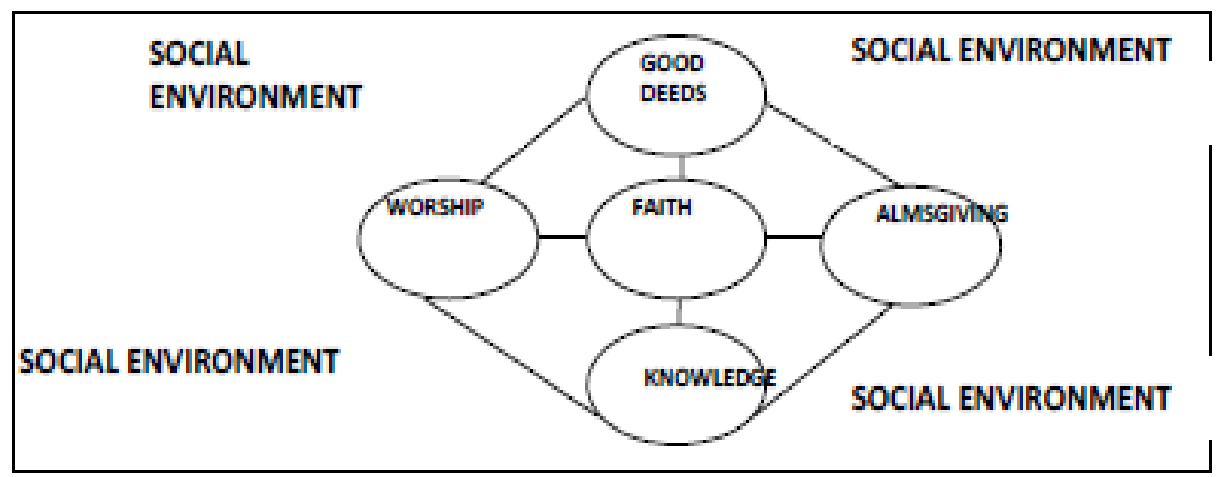

Figure 3: Relationship between Dimensions of Religious Behavior of Students at Excellent State Schools in North Sumatra

Aqidah is basically embedded since humanity was in the state of azali, before the birth of humanity. In humanity, there has been knowledge of Allah, love for Allah, and commitment to carry out the commands of Allah. All of them are all natural. The potentials above can develop well if the rules and behavior of the people living around them are in line with that potential. Religion created by Allah plays a role and guide people to the aforementioned potentials of aqidah to develop optimally. Unfortunately, the potentials of aqidah are not developed because religion is not introduced and enlivened by its environment. As they neither know religion properly nor live it up in their daily activities, the natural tendency becomes stale.

In situations without this religious influence, one will develop with dominance from the way of behaving, the acts, and living habits of the school environment. For example, all people who essentially want to keep themselves in holiness, but then find themselves in an environment that allows them to do any kind of unreasonable behavior (such as doing drugs, drinking alcohol, and promiscuity), will make them to eventually bring out their own negative behavior. This aqidah dimension, therefore, will grow rapidly when the school environment practices worships, almsgiving, good deeds, and stimulates them to improve and strengthen mastery of knowledge. Matters of knowledge are also highly important. Having knowledge of aqidah, worships, and almsgiving will make one's religion reach the optimum level. Thereby, it can be said that all dimensions of religiosity in Islam are interrelated with each other. 


\subsection{The Management of Excellent School in Instilling Religious Behavior to the Students of State High Schools in North Sumatera Province}

\subsubsection{SMA Negeri 2 Plus Martabe Sipirok Tapanuli Selatan}

The management of SMA Negeri 2 Plus Martabe Siporok South Tapanuli in instilling the religious behavior to the students is visible from the Vision, Mission and Targets included in this school's activity planning. The vision of SMA Negeri 2 Plus Martabe Siporok Tapanuli Selatan is clearly illustrated to produce graduates who excel in science and technology, IMTAQ insight and environment as well as character based on the norms of customs of Tapanuli Selatan. Below is the vision and mission of SMA Negeri 2 Plus Martabe Siporok Tapanuli Selatan according to the School Development Plan (RPS) document. SMA Negeri 2 Plus Martabe Siporok South Tapanuli has implemented the mandate of Regulation of Minister of Education and Culture Number 19 of 2007 on educational management standard by elementary and secondary education unit, program planning is marked by the formulation of vision, mission, goals, and work plan of the school. In terms of school planning, the principal has also involved all members of the school, the community, and Martabe Foundation in formulating the vision and mission of the school.

As known, the establishment of this school is an initiative of late Purn. Raja Inal Siregar who served as Governor of North Sumatra Province as well as the founder of Martabe Foundation. Raja Inal Siregar has a program "Marsipature Huta $\mathrm{Na} \mathrm{Be"} \mathrm{(Martabe)} \mathrm{which} \mathrm{means} \mathrm{"build} \mathrm{your}$ hometown". The establishment of this school has the full support of "man power" from the authority of North Sumatra Province.

The social approach used in the establishment of this school was based on the community's need for quality education. Raja Inal Siregar, therefore, collected people who were considered successful outside of North Sumatra to take part in here, specifically in Tapanuli Selatan Regency. "Marsipature Huta $\mathrm{Na} \mathrm{Be"} \mathrm{program} \mathrm{also} \mathrm{become} \mathrm{the} \mathrm{inspiration} \mathrm{for} \mathrm{other} \mathrm{regencies} \mathrm{to} \mathrm{set} \mathrm{up} \mathrm{quality}$ schools.

In line with the opinion of Koontz (2010), the principles that must be considered in the preparing/ planning, so that: 1) it must really give retribution to purpose and objective); 2) it shall be conducted at all levels, starting from the leadership to the subordinate level, according to the scope of activities done (pervasiveness of planning); 3) it has high efficiency values of planning. In addition, there are three approaches to make use of in educational planning: 1) "social demand" approach linked to the demands of society; 2) "Man power" approach linked to the development of personnel via the education to meet the demand of economic sector; 3) The "benefit" approach,

Which is the approach considering the benefits gained beyond the expenditure of educational budget (George Psacharopoulos: 2011: 355-358).

Clear visions and missions at SMA Negeri 2 Plus Martabe make it as an excellent school with a good system with the following characteristics: First, a stable school's academic atmosphere is present. Second, it has a school culture capable of creating discipline and high responsibility. Third, there is a clear arrangement of duties and responsibilities for the school community. Fourth, it is not easily shaken by internal and external problems. Fifth, it has a strong cooperation with 
various parties. Sixth, it is able to apply ICT in the school management. Seventh, it has strong principal leadership. Eighth, it has a high degree of sustainability.

In the case of implementation of excellent school management at SMA Negeri 2 Plus Martabe Sipirok Tapanuli Selatan, they work in cooperation with Martabe Foundation, including in their financing and supervision. In the development and improvement of the management of SMA Negeri 2 Plus Martabe Sipirok Tapanuli Selatan, these aspects are included therein: the development of school environment, strengthening the role of community, school culture.

With regard to student behavior of SMA Negeri 2 Plus Martabe Sipirok Tapanuli Selatan is shown clearly very that students' religious behavior is included in faith dimension, as marked by the students' belief in religion; while the worships dimension is marked by the worship activity done by the students together at school or in the dormitory, Monday- Thursday fasting, Qur'an recital between the Magrib (sunsets) and Isya (afternoon). Almsgiving dimension is characterized by the students' social activities, such mutual assistance, and aid donations. Ihsan dimension is characterized by sincerity of students in performing worship and social activities. Knowledge dimension is characterized by students' achievement in Arabic competition activities, and lecture is done in rotation by the students after morning prayers. Belief within a person will encourage him to behave according to his or her religious teachings. The level of a person's religiosity can indeed be displayed in an attitude and behavior.

SMA Negeri 2 Plus Martabe Sipirok Tapanuli Selatan is a school founded on cooperation between Martabe Foundation and Education Office of North Sumatera Province in order to get quality education. Teamwork between the Foundation and Education Office is still present to this day in terms of the school's management, starting from the planning, implementation and supervision. That is to say Martabe Foundation is always involved in the management of human resources, curriculum programs and financing. In this case, the instillation of religious behavior to the students can be directly controlled by the presence of full-day school and boarding school programs.

\subsubsection{SMA Negeri Plus 1 Matauli Pandan Tapanuli Tengah}

The management of SMA Negeri 1 Plus Matauli Pandan Tapanuli Tengah in instilling religious behavior to the students is evident from the strengthening of the Islamic learning system through humanistic approach. It is in contrast to SMA Negeri 2 Plus Martabe, but it is quite basic pdue to the heterogeneity of students and teachers there. SMA Negeri 1 Plus Matauli Tapanuli Tengah is a favorite school in North Sumatra. It is evidenced by the students coming from many other districts in North Sumatra and outside North Sumatra. Such circumstances mean the students come from various religions, ethnicity and clans. In this case, the instillation of students' religious behavior is focused on almsgiving dimension, such as mutual cooperation, obedience to parents, and respect for others.

The learning management with humanistic approach in this school is done through the problemsolving exercises adjusted to learning objectives, combined with adapted materials and methods, and learning materials of Islamic Education related to surrounding real life of the learners. 
The instillation of religious behavior to the students at SMA Negeri 1 Plus Matauli Pandan Tapanuli Tengah focuses on the formation of common sense, individualism (towards independence), responsibility, extensive knowledge, and respect for others (pluralism). This school is more concerned with the function of religion as a social activity which falls into almsgiving dimension for instilling religious behavior to the students.

So, no wonder when the researchers visited this high school, they saw the students who behaved politely to any guest. This same also applies to all teachers and employees here. This students' behavior shows the applicable habituation at SMA Negeri 1 Plus Matauli Pandan Tapanuli Tengah. This is in line with Abdurrahman Mas'ud's view (2012: 193), stating that the concept of humanistic in learning process is a religious concept that places human beings as human beings, as well as a form of humanization efforts of sciences, while paying attention to the responsibilities of hablum minallah and hablum minannas.

SMA Negeri 1 Plus Matauli Pandan Tapanuli Tengah is a school that implements full-day school and boarding school programs. The instillation of religious behavior to the students, students' religious behavior can be directly controlled by teachers and boarding house caretakers. Although the instillation of religious behavior of the students here does not come from the faith dimension programmed by the school, the values developed in this school are similar to those of religious behavior in Islam. It is in line with Umar (2014: 437), stating that religious behavior is a measurable, calculated and studied expression of human life, manifested in words, deeds or actions related to the experience of Islamic teachings. The behavior, physical actions of words and deeds of the students here have reflected Islamic religious behavior.

\subsubsection{SMA Negeri Plus 2 Panyabungan Mandailing Natal}

The management of excellent school carried out in SMA Negeri 2 Plus Panyabungan Mandailing Natal in instilling religious behavior to the students is reflected in the vision, mission and goals. The data of School Development Plan (RPS) of SMA Negeri 2 Plus Panyabungan Mandailing Natal clearly illustrate the objective of this school is to bring forth intelligent and religious students accompanied with cultural and characteristic values of the nation. The vision, mission and goal illustrate that the management is integrated in every activity program implemented in this school. The findings on the field show that despite being a public school, the management of boarding school program in SMA Negeri 2 Plus Penyabungan resembles to that in Islamic boarding schools, in terms of the development of the students' religious behavior. Activities in the dormitory and school are the full responsibility of school management.

The history of the establishment of SMA Negeri 2 Plus Penyabungan stands on the public's wishes for quality school in Mandailing Natal, following the example of SMA Negeri 2 Plus Matauli and SMA Negeri 2 Martabe Sipirok. Many people who sent their children to these two schools. The people, thereby, yearned for an excellent school in Mandailing Natal Regency, just like those in Tapanuli Tengah and Tapanuli Selatan Regencies. A flagship class was set up in 2003. It was pioneered by the Mandailing Natal community who lived in the vicinity of Medan under Consultative Body of the Mandailing Natal's Scholars (BMCMN), led by Ir. Zulkarnain Lubis, MS who was also the Rector of Medan Area University. This flagship class was under the umbrella of SMA Negeri 1 Kotanopan. In 2006, Mandailing Natal Regency Government decided to 
immediately change the status of the flagship class into a stand-alone school, SMA Negeri Plus, thus turning all students there into the students of SMA Negeri Plus, and Ir. Zulkarnain Lubis, MS. was asked to be the headmaster.

The boarding school programs at SMA Negeri 2 Plus Panyabungan are designed to resemble those in Islamic boarding school, yet the boarding school programs here are not coercive. It is in accordance with the motto of SMA Negeri 2 Plus Panyabungan: "Acting By Heart, SMA Plus Jaya, SMA Plus Jaya, SMA Plus Jaya.”

In terms of religious behavior of students here, it can be seen from the religious culture created in the school environment: doing religious activities; inculcating honesty; discipline; responsibility; independency; and persistence in practicing the command of Allah, be it in the form of obligatory worships, circumcision, and the integration of akhlakul karimah education with lesson subjects.

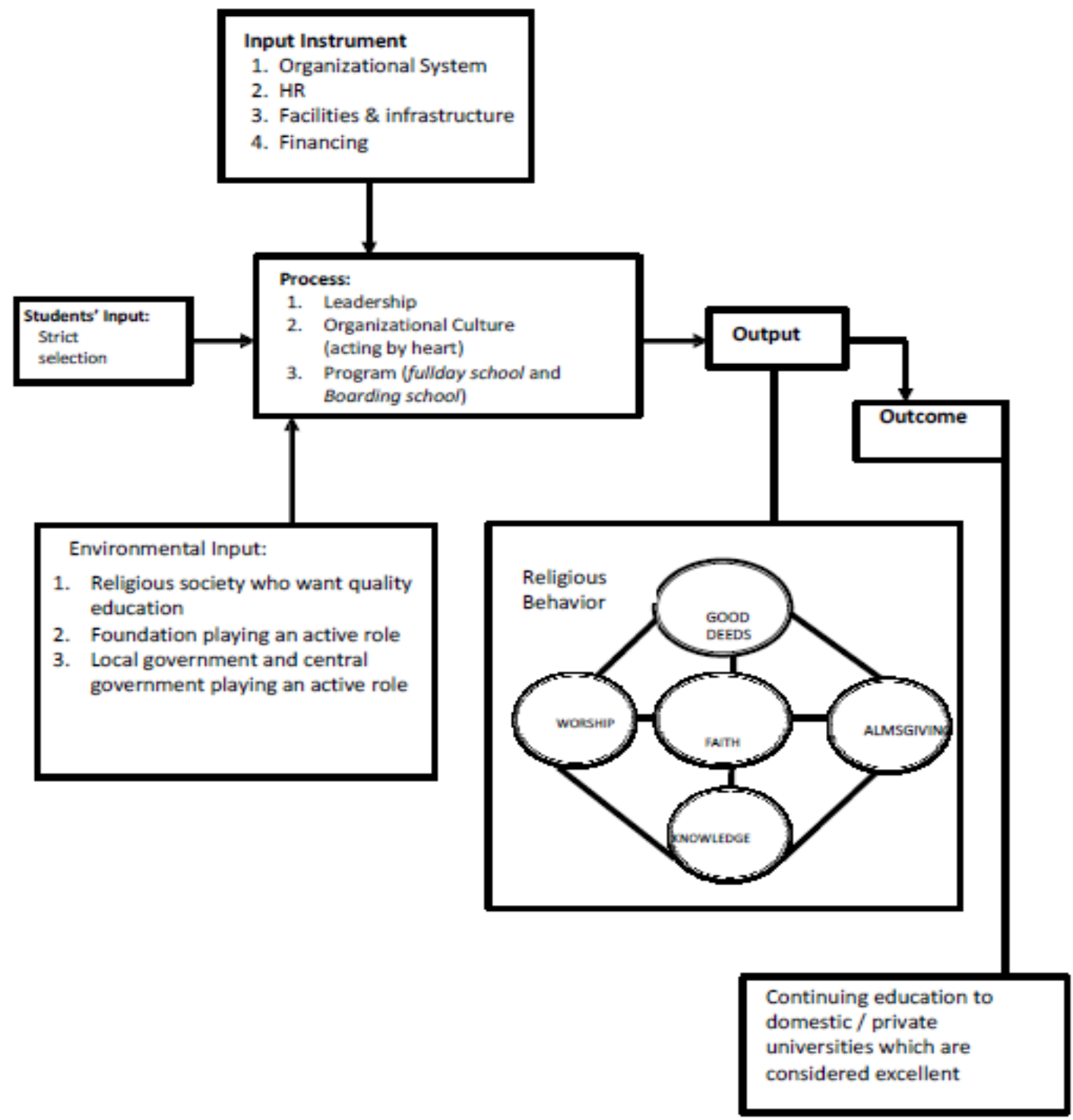

Research Findings in the Management of Excellent Schools in Instilling Religious Behavior to the Students of State High Schools in North Sumatera 
Explanation of the figure above is shown below:

Student Input: All of the three schools that served as objects in the research accepted the students through a rigorous selection process (academically, physically, spiritually, via written tests and interviews).

Input Instrument: The organization system, facilities and infrastructure, quality human resources and strong financing. These are obtained from the selection of human resources and placement of employees according to their competence or direct man and direct place. The selection can be done by involving the stakeholders in a rigorous selection process. Strong financing means the fulfillment of complete and luxurious facilities \& infrastructure.

Environmental Input: It is an external and internal environment that supports excellent school sustainability in instilling religious behavior of the students. Environmental inputs of excellent school's management in instilling religious behavior of students is found in religious society who cares about the quality of education, foundation, local and central government, that play an active role in the management of excellent schools in instilling religious behavior to the students.

The process is leadership in the organizational culture, full-day schools, and boarding schools program. The principal of excellent school as a leader should always strive to gradually and sustainably improve his intellectual ability, management, personality, skills, communication, so that he will earn the characteristics of a strong and internationally-capable school principal. Leadership in excellent school management should be supported by organizational culture. An advanced organizational culture can be seen from the human abilities, the abilities of institutions/ organizations, as well as the abilities of the system. In organizational culture, there are actually three main dimensions to make improvement for excellent schools: (1) workers (dimension of Human Resources), involving the quality of human resources and the way HR is being taken advantage of; (2) capital (physical dimension); (3) technology, namely the organization and management style, planning function, policy determination, controlling and evaluation, communication, and management information system.

Output: Students have a religious behavior which comprises these five dimensions: 1) faith dimension, namely the belief in religion (Islam); 2) worships dimension, namely the religious ritual activities, such as prayers, fasting and charity, 3) almsgiving dimension, namely social behavior to the environment and society, such as discipline, honesty, mutual assistance, neatness, pluralism; 4) good deeds dimension, such as performing worships and charity sincerily and heartedly, 5) knowledge dimension, namely knowledge of the religion being embraced.

Outcome: the graduates from excellent schools can continue their education to state and private universities that are considered excellent, either domestically or internationally.

\section{Conclusion}

The success of excellent school management is strongly influenced by inputs and processes in determining the output and outcome of the students' religious behavior. Second, the management of excellent schools in North Sumatra involves all concerned components, such as foundation, government and the society, starting from the planning, implementation, supervision to financing. Third, religious behavior of the students in North Sumatra constitutes Faithful Behavior, namely the students' belief in religion, worships behavior, religious rituals in schools; Almsgiving Behavior, namely the discipline, cleanliness maintenance, mutual assistance in pluralism; Good 
Deeds Behavior, namely the students' sincerity in worships and doing charities; and Knowledge Behavior, namely the students' knowledge in religion teachings. Fourth, the management of excellent schools in North Sumatra in instilling religious behavior to the students is integrated in the system of humanistic learning approach, full-day school and boarding school programs.

\section{References}

[1] AbdurrahmanMas'ud, (2012) MenggagasFormatPendidikanNonDikotomikHumanisme religious Sebagai Paradigma Pendidikan Islam. Yogyakarta. GammaMedia.

[2] Depertemen Pendidikan dan Kebudayaan, (1994) Pengembangan SMA Plus, Jakarta: Direktorat Jenderal Pendidikan Dasar dan Menengah.

[3] Indonesia, P. R. (2005). PeraturanPresiden RepublikIndonesia Nomor7Tahun 2005 Tentang Rencana Pembangunan Jangka Menengah Nasional Tahun 2004-2009.

[4] Koontz, H. (2010). Essentials of management. TataMcGraw-HillEducation.

[5] Matthew B. Miles, A.MichaelHuberman,JohnnySaldana(2014)QualitativeDataAnalysis, London. Sage.

[6] Nasional, S.P. (2003). Undang-Undang Republik Indonesia Nomor 20 Tahun 2003.Jakarta, Depertemen Pendidikan Nasional Republik Indonesia.

[7] Pavlov, P.I. (2010). Conditioned reflexes: an investigation of the physiological activity of the cerebral cortex. Annals of neurosciences, 17(3), 136.

[8] Pendidikan, B. S. N. (2007). Standar Proses untuk Satuan Pendidikan Dasar dan Menengah. Badan Standar Nasional Pendidikan.

[9] Pendidikan, P. (2007). Peraturan Menteri Pendidikan Nasional Republik IndonesiaNomor63 Tahun 2009.

[10] Psacharopoulos, G. (Ed.). (2014). Economics of education: Research and studies. Elsevier.

[11] Robert K. Yin, (2016) Qualitative Research from Start to Finish, Second Edition, The Gulid Ford Press. New York. London.

[12] Sahlan,A.(2010). Mewujudkan Buday Religiusdi Sekolah: Upaya Mengembangkan PAI dari Teori keAksi. UIN-Maliki Press.

[13] Sergiovanni,T.J.(1987). The Principal ship: A Reflective Practice Perspective. Publication Sales, Allyn andBacon,LongwoodDivision, 7 Wells Avenue, Newton, MA 02159.

[14] Talizuhu Ndara, (2010) Teori Budaya Organisasi, Jakarta: RinekaCipta.

[15] Umar, H. N. (2014). Deradikalisasi Pemahaman Al Quran dan Hadis. Elex Media Komputindo. _-

*Corresponding author.

E-mail address: martinisyamin@yahoo.co.id 